\title{
Effect of Urea Application as a Top Dressing on Development of Black Heart Disorder of Mauritius Pineapple (Ananas comosus L.) During Cold Storage
}

\author{
K. H. Sarananda
}

\begin{abstract}
Pineapple variety "Mauritius" has a high export demand due to its characteristic flavor. However, the demand cannot be fulfilled due to internal browning that occurs during sea freight especially when the storage period under refrigerated condition at $10-12{ }^{\circ} \mathrm{C}$ is extended more than two weeks. The inherent nature of poor distribution of calcium around core area causes this disorder. Some evidences are available on prevalence of this disorder even before 2 weeks in refrigerated storage, if urea fertilizer is applied as a top dressing exceeding the recommended level. This study was conducted to find out the effect of urea application as a top dressing on Black Heart Disorder of pineapple during simulated sea freight conditions. urea was applied as top dressing to leaf base of plant when fruits were at one month after flowering. The level of urea applied was 10 and 20 g per plant and control plots were arranged in completely randomized block design with three blocks in farmer field at Attanagalla, Gampaha district. Except the top dressing all other requirements were provided based on the recommendations of Department of Agriculture. Fruits were harvested at green mature stage and were stored in a pre- cooled refrigerator maintained at $12{ }^{\circ} \mathrm{C}$ for 15 days. Subsequently, fruits were transferred to ambient temperature and shell colour development, intensity of black heart disorder and physico-chemical parameters were recorded after 2, 4 and 6 days. Results showed that application of urea $20 \mathrm{~g} /$ plant enhanced black heart disorder compared to other treatments. It was also observed that nitrogen level of fruit tissues of these fruits were significantly higher than the control and the urea applied at $10 \mathrm{~g} /$ plant. In addition, significant reduction of ascorbic acid and pH was also observed with $20 \mathrm{~g} /$ plant urea application.
\end{abstract}

Food Research Unit, Department of Agriculture, Peradeniya, Sri Lanka. sarahewa62@yahoo.com
Based on these results it can be concluded that 20g / Plant urea application as top dressing increases nitrogen content of fruit tissues around core area and, reduces ascorbic acid which results in onset of Black Heart Disorder of pineapple during cold storage.

Key words: Ascorbic acid content, Black Heart Disorder, Calcium deficiency, Cold storage, Increased nitrogen level

\section{INTRODUCTION}

Mauritius pineapple has a high
export demand due to inherent characteristic flavor and golden yellow color. However, sea shipment is restricted owing to the temperature related physiological disorder called Black Heart Disorder (BHD) which is also known as internal browning (Dull, 1971). The severity of the disorder is clearly influenced by low temperature and duration of the exposure to higher temperature after removal from the cold store (Alles, 1998).

Prolonged exposure to low temperature results in increase content of phenolic compounds and polyphenol oxidase (Hussain et al., 1999). Initial symptoms of this disorder is formation of water soaked lesions around the core in affected area of the fruit. These symptoms however, are undetectable externally since the fruit appears normal (Nanayakkara, 1991), and fruits with the symptoms are heavily downgraded in the canneries and cannot be included as slices in consumer packs. However, fruits with mild symptoms can be juiced (Abdulla and Rohaya, 1983). Tay (1974) reported that fruit sugar and acid contents were lowered with increased 
application of nitrogen. Ascorbic acid is known to be a browning inhibitor which reduces the forward browning reaction (Abdullah and Rohaya., 1983). Ascorbic acid content is decreased with increased nitrogen supply. Further, the highest level of disorder had been observed in fruits harvested from the plants exposed to high nitrogen.

Farmers unaware of this problem and their aim is to increase their profit by harvesting bulky fruits by application of high dosage of urea $\left(\mathrm{CH}_{4} \mathrm{~N}_{2} \mathrm{O}\right)$. At the mean time sea freight was not possible if the duration exceeded more than 2 weeks under refrigerated transport. Hence this study was conducted to find out the effect of excessive level of urea application to the leaf base of pineapple plants on BHD development of fruits stored at refrigerated temperature.

\section{MATERIALS AND METHODS}

\section{Experimental Treatments}

A newly established plantation of Attanagalla, Gampaha district was selected for the study. Treatments consisted urea application as top dressing zero g/plant, 10 g/plant and $20 \mathrm{~g} /$ plant. Experimental plots were randomly arranged in each block and three blocks were used. Plants were induced for flowering by treating with Ethral. The urea top dressing was applied according to the Treatments described above and urea was applied on leaf base of fruited plants. The fertilizer recommended by Department of Agriculture, Sri Lanka was used until flower induction and the excess urea was added 3 1/2 months after flower induction.

Fully mature fruits were harvested from all treatments and transported to the laboratory at Food Research Unit using plastic crates. Fruits were cleaned and brushed to remove insects. Fruit stalks were trimmed to a length of $2.5 \mathrm{~cm}$ using a cross cut. The cut end of stalks was dipped in fungicide solution 400 ppm Chlorothalonyl to control fungal rots taking place at the cut end of the stems. Once the applied fungicide was dried, fruits were placed in a refrigerator after enclosing in 5ply corrugated fiberboard boxes. These boxes were immediately stored in a cold room maintained at $12{ }^{\circ} \mathrm{C}$ and $80-85 \%$ RH for 15 days to simulate shipping conditions followed by a holding period of 3 days at ambient temperature at $28{ }^{\circ} \mathrm{C}$.

\section{Data Measurement}

Three representative samples were analyzed for Physico-chemical parameters before placing fruits in the cold room. Cores removed from the middle $1 / 3$ of the fruits were used for analysis. Brix value was recorded by using few drops of extract from selected samples using a hand held Refractometer. The squeezed juice was used to measure $\mathrm{pH}$ of fruits using a $\mathrm{pH}$ meter (Model 3510 JENWAY).

Ascorbic acid was measured based on reduction of 2 - 6 - Dichlorophenol indophenol method (AOAC, 1984). The flesh colour of fruits was recorded using an index 1: Pale yellow, 2: Yellow and 3: Golden yellow (Wijerathnam et al., 1993). The BHD was assessed in longitudinally halved pineapples using the scale described by Abdullah et al., (1983). The scale used was 0: good flesh with no discolouration and 5: 100\% flesh discoloured. The shell colour of pineapple was determined visually using a scale described by Wijerathnam et al. (1993). The scale used was 0: full green and 5: 100\% Yellow. Sensory evaluation was recorded using a panel of 30 members using the hedonic scale 1-5. Flesh colour, taste, aroma and overall acceptability were recorded as sensory parameters. The weight of each fruit was recorded before and after cold storage and the difference in weight was converted to percentage weight loss. The 
experiment was laid out in the field using Randomized Complete Block Design and laboratory experiments were designed based on Completely Randomized Design. Parametric data was analyzed using ANOVA, SAS package. Means were separated using DMRT 5\% level and nonparametric data was analyzed using freedman test, MINITAB.

\section{RESULTS AND DISCUSSION}

Peel colour development of all fruits reached its maximum level full yellow (5.0) 4 days after removal from the cold storage (Table 1). This shows that no chilling damaged occurred to the shell during 14 days of cold storage. There was no significant difference in peel colour among treatments at each day after removal from the cold room. Though the peel colour increased at 4 days after removal from the cold storage, no significant increase in flesh colour was observed. This may be due to non- climacteric nature of the flesh. Peel colour development after removal from the cold storage was similar to observation recorded by Fernando and De Silva (2000). Though the peel colour development was recorded in all fruits of their reported experiment, there was no flesh colour development, proving the non- climacteric nature of the flesh.
Table 2 shows that BHD was observed in all fruits at each observational time starting from day 4. However, the intensity of browning after removal from cold storage was significantly higher in urea treated plants at the rate of $20 \mathrm{~g} /$ plant. BHD level was always the lowest at each observation time in control treatment. Results clearly showed that higher level of urea application as a top dressing enhanced the BHD of pineapple.

Ascorbic acid content of all pineapples before storing them at cold storage was at high level (Table 3). However, ascorbic acid levels were drastically reduced in all treatments during cold storage. The reduction was high in all fruits under refrigerated storage. The lowest ascorbic acid content was observed at 4 days after removal in fruits treated with 20 $\mathrm{g}$ of urea. The similar trend was observed at 5 and 6 days after removal from cold storage. This may be due to increased level of nitrogen that reduces the level of ascorbic acid. There was a relationship between high level of urea and BHD and at the mean time onset of BHD was related to decreased level of ascorbic acids. The highest level of BDH has been observed in fruits harvested from plants which received higher level of urea (Selvarajah, 1999).

Table 1: Shell colour and peel colour development of pineapple after removal from the cold storage.

\begin{tabular}{lllllllll}
\hline \multirow{2}{*}{$\begin{array}{l}\text { Level of urea applied per } \\
\text { plant }\end{array}$} & \multicolumn{3}{c}{$\begin{array}{c}\text { Shell colour } \\
\text { Days after removal }\end{array}$} & \multicolumn{5}{c}{ Flesh colour } \\
\cline { 2 - 11 } & 1 & 2 & 3 & 4 & 1 & 2 & 3 & 4 \\
\hline Urea 10 g/ plant & 1.5 & 2.9 & 4.2 & 5.0 & 2.6 & 2.8 & 2.8 & 2.9 \\
Urea 20 g/ plant & 1.4 & 2.8 & 4.3 & 5.0 & 2.7 & 2.9 & 2.6 & 2.9 \\
Control & 1.2 & 3.0 & 4.5 & 5.0 & 2.8 & 2.7 & 2.8 & 2.9 \\
$P$ & 0.18 & 0.71 & 0.77 & 0.36 & 0.26 & 0.81 & 0.53 & 0.26 \\
\hline
\end{tabular}




\section{K. H. Sarananda}

Shell colour index : 0 -10\% yellow, 1-30\% yellow, 2-50\% Yellow, 3-75\% Yellow, 4- 95\% Yellow and 5-100\% yellow. Flesh colour index: 1 - Pale yellow, 2- Yellow and 3 - Golden Yellow.

Table 2: Severity of BHD of pineapple fruits stored at ambient temperature after removing from the cold storage.

\begin{tabular}{llcc}
\hline Treatment & \multicolumn{3}{c}{ Days after removal from the cold storage } \\
\cline { 2 - 4 } & 4 & 5 & 4.3 \\
\hline Urea 10g / Plant & 3.0 & 3.5 & 4.7 \\
Urea 20g/ Plant & 4.0 & 4.3 & 3.2 \\
Control & 2.3 & 3.1 & 0.001 \\
P. Value & 0.002 & 0.001 &
\end{tabular}

BHD index: $1-<10 \%$ area discoloured, $2-<25 \%$ area discoloured, $3-<50 \%$ area discoloured, $4-<75 \%$ area discoloured, $5-100 \%$ area discoloured.

Table 3: Ascorbic acid content (mg/100g) of Pineapple fruit

\begin{tabular}{lllll}
\hline Treatment & \multicolumn{4}{l}{ Day after removal from Cold storage } \\
\cline { 2 - 5 } & Initial & 4 & 5 & 6 \\
\cline { 2 - 5 } Urea 10g / Plant & $22.61 \mathrm{a}$ & $3.0 \mathrm{a}$ & $3.5 \mathrm{~b}$ & $4.3 \mathrm{~b}$ \\
Urea 20g/ Plant & $22.61 \mathrm{a}$ & $4.0 \mathrm{~b}$ & $4.3 \mathrm{c}$ & $4.7 \mathrm{c}$ \\
Control & $22.61 \mathrm{a}$ & $2.3 \mathrm{a}$ & $3.1 \mathrm{a}$ & $3.2 \mathrm{a}$ \\
\hline
\end{tabular}

Treatment means in a column having common letters are not significantly different at $p<0.05$

Table 4: Total nitrogen content in plant parts before cold storage

\begin{tabular}{lll}
\hline Treatments & Fruit tissue N (mg/g) & Leaf tissue N (mg/g) \\
\hline Urea 10g / Plant & $5.53^{\mathrm{b}}$ & $10.77^{\mathrm{a}}$ \\
Urea 20g / Plant & $7.02^{\mathrm{a}}$ & $13.27^{\mathrm{a}}$ \\
Control & $5.30^{\mathrm{b}}$ & $13.47^{\mathrm{a}}$ \\
\hline
\end{tabular}

Treatment means in a column having common letters are not significant different at $p<0.05$

There was a significant difference in leaf nitrogen when adding urea (Table 4). This may be due to mobility of $\mathrm{N}$ to other parts of the plants. However, there was a significant increase in $\mathrm{N}$ in fruit tissues which were harvested from plants added with $20 \mathrm{~g}$ urea/ plant. Application of urea 10 g/plant did not show an increase in nitrogen level in fruit tissues. The occurrence of BHD mainly due to oxidation of phenolic compounds by polyphenol oxidase to form brown products. That may be due to softening of fruit cells by increased levels of nitrogen. Softened cells are easily collapsed in response to chilling resulting in high intensity of browning.

Significantly higher TSS values were observed in control fruits (Table 5). TSS values were reduced in fruits applied with both levels of urea. Higher $\mathrm{pH}$ values were recorded in both urea applied treatments compared to the control. This may be due to increased levels of Ascorbic acid in control fruits (Table 3). The maximum levels of TA was recorded in control fruits. Both urea applied fruits showed significantly reduced TA.

Significantly higher TSS was recorded in control fruits at 6 days after 
removal from the cold storage (Table 6). The similar trend in reducing TSS in fruits treated with urea showed in fruits before cold storage. No difference in $\mathrm{pH}$ was observed among treatments. Further no significant difference in TA was observed among treatments.

Internal browning of pineapple during cold storage is a serious problem during sea freight (Paul and Rohrbach, 1985). The same problem has been reported in Mauritius pineapple by Selvarajah and Hearth (1977).

Further, it has been reported that there is no change in physico-chemical parameters such as total soluble solids, $\mathrm{pH}$, colour etc. However, the symptoms are developed only around core area and even at severe incidence, no externally developed symptoms appear. This incidence was developed in the core area due to tissue degradation in response to long exposure to low temperature which is termed as chilling injuries. Once cell walls and cell membranes are damaged the effect of compartmentalization of the enzyme polyphenol oxidase and the substrates disturbs resulting browning reaction (Paul and Rohrhach, 1982). Further studies carried out on this disorder showed that the reason for affecting the disorder around the core area is reported as prevalence of low level of calcium compared to the peripheral area of fruit tissues (Hewajulige et al., 2003). The reduced concentration gradient of calcium is an inherent factor associated with Mauritius pineapple. Reduced calcium weaken the cell membranes and cell walls resulting susceptibility to damage in response to chilling. Soil application of calcium during planting has reduced the incidence to a certain level (Selvarajh, 1999). However, pre-harvest application of calcium in soluble form prevents the disorder for 3 weeks of storage and can be extended up to one month with slight defects (Hewajulige et al., 2006). Based on those evidence it is clear that one of the causes for the disorder is reduced level of calcium around core area and the level can be increased by combination of calcium application during planting and pre-harvest calcium spray.

Table 5: Total soluble solids (TSS), $\mathrm{pH}$ and Titratable acidity (TA) of Pineapple before Cold storage.

\begin{tabular}{llll}
\hline Treatments & \% TSS & pH & TA (\%Citric acid) \\
\hline Urea 10g / Plant & $10.1^{\mathrm{b}}$ & $3.8^{\mathrm{a}}$ & $0.05^{\mathrm{b}}$ \\
Urea 20g / Plant & $10.2^{\mathrm{b}}$ & $3.7^{\mathrm{a}}$ & $0.05^{\mathrm{b}}$ \\
Control & $11.3^{\mathrm{a}}$ & $3.6^{\mathrm{b}}$ & $0.10^{\mathrm{a}}$ \\
\hline
\end{tabular}

Treatment means in a column having common letters are not significantly different at $p<0.05$

Table 6: Total soluble solid (TSS), $\mathrm{pH}$ and titratable acidity of pineapple at 6 days after removal from cold storage.

\begin{tabular}{llll}
\hline Treatments & \% TSS & pH & TA (\% Ascorbic acid) \\
\hline Urea 10g / Plant & $10.9^{\mathrm{b}}$ & $3.1^{\mathrm{a}}$ & $0.05^{\mathrm{a}}$ \\
Urea 20g / Plant & $10.8^{\mathrm{b}}$ & $3.1^{\mathrm{a}}$ & $0.05^{\mathrm{a}}$ \\
Control & $11.6^{\mathrm{a}}$ & $3.2^{\mathrm{b}}$ & $0.05^{\mathrm{a}}$ \\
\hline
\end{tabular}

Treatment means in a column having common letters are not significantly different at $p<0.05$ according to DMRT mean separation procedure 
Though the exact physiological explanation for the disorder is calcium mediated, excessive nitrogen fertilizer application can influence the disorder. Application of urea as a top dressing to increase the fruit size, is a common practice adopted in Sri Lanka. Preliminary observations showed that such fruits developed the disorder even early as one week of cold storage. Results of this study showed application of urea at $20 \mathrm{~g} /$ plant enhanced the disorder compared to $10 \mathrm{~g} /$ plant application. Tissue Nitrogen analysis showed higher level of nitrogen around core area in urea treated plants compared to untreated control. This is a clear evidence for which increased level of nitrogen may decreased the strength of cell membrane resulting de-compartmentalization of enzymes and substrates responsible for browning. Further, it was also observed that Ascorbic acid content of pineapple had decreased in response to urea application. This may be another reason to enhance the forward reaction of browning because low acidity enhances the enzymatic browning reaction. Significant reduction of Ascorbic acid in urea treated fruits even after removal from the storage showed a clear relationship between Ascorbic acid and the disorder.

\section{CONCLUSION}

The application of urea as a top dressing increases the fruit size, soften the tissue around core area especially due to presence of low calcium. Hence top dressing of Urea enhance the tissue susceptibility to damage during cold storage resulting accelerated browning. However, application of Urea can be practiced up to $10 \mathrm{~g} /$ plant without disturbing the tissue degradation and at $20 \mathrm{~g} / \mathrm{plant}$ level caused serve browning. BHD was observed in control fruits where no nitrogen was applied indicating that the inherent property of low calcium around core tissue. Thus, the effect of Urea application as top dressing need to be further investigated in plants enriched with calcium by pre-harvested application.

\section{ACKNOWLEDGEMENT}

Ms. N.D.K Paranamana is greatly acknowledged for the support given on analytical work.

\section{REFERENCES}

A.O.A.C. 1984. Official methods of analysis of the AOAC. Arlington, Va., USA: Association of Official Analytical Chemists.

Alles, N.H (1998). Report on a literature survey and a hypothesis surrounding the occurrence of endogenous brown spot (EBS) of pineapple. CISIR

Abdullah, H. and Rohaya, M.D.A (1983). The development of black heart disease in Mauritius pineapple (Ananas comosus cv. Mauritius) during storage at low temperatures. MARDI Research Bulletin 11(3); 309 -319.

Dull, G.G. (1971). The pineapple: General. In the Biochemistry of fruits and their products. (Lcd) A.C Hulme. Academic Press, New York, USA.

Feranando, M.F.S.W. and De Silva, P.H.J.C. (2000). Postharvest handling of Mauritius pineapple Ananas comosus at ambient temperature. Annals of the Sri Lanka Department of Agriculture. 4: 359 - 366.

Hewajulige, I.G.N, Wijerathnam, R.S.W and Wijesundara, R.L.C. (2006). Preharvest application of calcium to control black heart disorder in Mauritius pineapple during low temperature storage. Journal of 
Science Food and Agriculture. 86: $420-424$.

Hussain, S.F., Suntharalingam, $S$ and Siriwardana, T.D.W. (1998 and 1999). The effect of packing on the control of internal browning of pineapple. Tropical Agriculturist 152: 33: 37.

Nanayakkara, K.P.A. (1991). Study of fruit core deterioration in pineapple (Ananas comosus cv. Mauritius) under cold storage. MPhil thesis, Postgraduate Institute of Agriculture, Peradeniya.

Paull, R.E. and Rohrbach, K.G. (1985). Symptom development of chilling injury in pineapple fruit. Journal of American Society for
Horticultural Science. 110 (1): $100-10$

Selvarajah, S. (1999). Pre and postharvest treatments for reducing the incidence of chilling injury in pineapple. Doctor of Philosophy thesis, PGTA, Peradeniya.

Tay, T.H. (1974). Effect of nitrogen and potassium on the growth, mean fruit weight and fruit quality of pineapple. MARDI Research Bulletin. 3(1) 1 -14.

Wijerathnam, R.S.W., Abeysekara, M. and Surajani, P. (1993). Study on black heart disorder in pineapple varieties grown in Sri Lanka. Acta Horticulture, 317 - 334. 